\title{
How Czech firms deal with operational budgets? - Survey results
}

\author{
Boris Popesko \\ Tomas Bata University in Zlin, \\ Zlin, Czech Republic \\ Email:popesko@fame.utb.cr.

\section{Jiř́ Dokulil} \\ Tomas Bata University in Zlin, \\ Zlin, Czech Republic \\ Email:dokulil@fame.utb.cr. \\ Dušan Hrabec \\ Tomas Bata University in Zlin, \\ Zlin, Czech Republic \\ Email:brabec@fai.utb.cz.
}

Abstract. In recent decades, academics and practitioners started a deep discussion about the limitations and perspectives of enterprise budgeting systems. Traditional budgets are frequently criticized due to their inflexibility, weak connection to corporate performance and demand on manager's time. Recently, we have observed more frequent examples of firms which have undertaken budgeting system transformation and the adoption of modern, flexible and performance-based budgets. In this study, we have studied some trends in the budgeting of Czech firms with a focus on the manager's behaviour. This paper contributes to the existing knowledge in two fields: Firstly, it summarizes the existing state of the art regarding the budgeting transformation; secondly, it presents the survey results focused on the operational budget utilization and its impact on the manager's behaviour. Overall, the study presents some findings regarding the impact of an operational budget on the manager's behaviour. We have tested how frequently situations occur, more specifically those frequently discussed in literature, in a given Czech firm's budgeting practices.

Keywords: budgeting, planning, organizational behaviour, behavioural accounting, beyond budgeting.

JEL Classification: L29 


\section{INTRODUCTION}

The role of budgeting as a traditional managerial tool was theoretically defined in the monographs of many well-known authors (Drury, 2000; Garrison et al., 2014; Horngren, 2009, etc.). Libby and Lindsay (2010) state that budgets historically play a key role in management control. This view is shared by Nazli Nik Ahmad (2003), who claims that budgeting is an integral element of the management control system. According to Hilton and Platt (2013), it is the most common method in the facilitation of planning and control.

Budgets are used in firms for various purposes (allocation of resources, coordination of individual activities) and are widely connected with measurable performance (Blocher et al., 2002, Wagner 2014). The budgeting system is often connected with the planning process (Ostergren \& Stensaker, 2011); Král (2010) considers budgets to be plans transformed into currency units. Hänninen (2013) states that in budgets, strategic ideas are transformed into operative activities. According to surveys by Banovic (2005) and Pietrzak (2013), almost $90 \%$ of interviewed firms use budgeting for planning, coordination of activities or for motivation and evaluation of staffs.

However, we must observe that the traditional budgeting systems have been objects of criticism for several decades and this criticism is visible all over the world, especially in developed countries. The discussion targets, especially the conflicting role of budgets, which are used for various purposes - for example, motivation and planning (Drury, 2000). Several controversial elements are discussed in the literature. They are: a lack of adaptability for unexpected changes of conditions; focus on results, not on causes; annual basis of financial reporting and outdated stereotypes of thinking which are supported in budgets (Hansen et al., 2003; Neely et al., 2003).

Criticisms of budgeting are analysed in detail in the publication of Neely, Sutcliffe and Heyns (2001). They compiled a comprehensive inventory of the twelve most cited weaknesses of budgeting. A strict view is presented by Hope and Fraser (2003), who claimed that budgeting is non-functional in a dynamic environment and should be cancelled. Other authors complement (Hänninen, 2013; Libby \& Murray, 2007), saying that traditional budgeting is a relic of the past ages and cannot be useful in conditions of changes and requirements of today's business world.

Budgets are also much criticized for being time consuming (Libby and Lindsay, 2010). Neely et al. (2003) examined in their research how the budgeting process consumes more than $20 \%$ of all managerial time. One of the most discussed limitations of the traditional annual budgets is the inflexibility of fixed budgets in the changing business environment. Hope and Fraser (2003) state that the current business environment is characterized by unpredictability; prices and margins are constantly under pressure and product life cycles are shorter.

The question is how to remove limitations of budgeting and effectively utilize potential budgeting. In current publications, we can observe the terms as traditional budgeting methods and alternative budgeting methods. Alternative budgeting methods include methods like Activity-Based Budgeting, Beyond Budgeting, Zero-Based Budgeting and Rolling Budgets. Their impact is based on focus and accuracy of budget outputs (Activity-Based Budgeting), improvement of forecast accuracy (Rolling Budgets) and the radical abandonment of old practices and ideas (Beyond Budgeting, Zero-Based Budgeting). Description of these methods and their impacts for theory and practice are objects of works by many appropriate authors (Cardos, 2014; Henttu-Aho \& Järvinen, 2013).

Cardos (2014) thinks that budgeting stands at a crossroads. It is not a simple choice to choose between traditional or alternative budgeting methods because each way produces its own direct or indirect effects throughout the organization. It generates a certain amount of interactions and non-intuitive outcomes. 
Despite deep scientific discussion regarding the limitations of the traditional budgeting, only limited evidence exists of radical developments, or of companies that have applied Beyond Budgeting. A simple explanation of this is fact that most transformations of budgeting practices or systems are both continuous and incremental, and take place over relatively long periods of time (Henttu-Aho \& Järvinen 2013). In a study published in 2015, we observe very few firms which plan to abandon the traditional use of budgets for control but a relatively modest number of firms which plan some changes in budgeting process (Popesko et al. 2015). Similarly Šřka (2016) has indicated in his Czech study the wider use of traditional Management Accounting techniques.

In our study, we have focused on some issues regarding the budgeting practices of Czech firms. The study focuses on some behavioural aspects of budgeting and issues related to its practical use. We have designed the study to be able to verify the presence of global trends in the Czech budgeting practice. This study tries to contribute to the knowledge by analysing the behavioural aspects of the budgeting in Czech Republic especially focused on the conflicting role of the budgets.

\section{METHODS}

The article is based on a questionnaire survey performed on a selected sample of Czech enterprises. The Albertina database was used as a source of contact information to individuals who are employed in financial management in small and medium-size companies. It included job positions as Financial Director, Economic Director or Head of Controlling Department as the employees responsible for budgets. The first step of the research was to call up these managers and ask them to participate in the survey. Totally, 1375 medium-size and large companies from industrial sector were addressed, 618 of them agreed to be surveyed and 177 completed questionnaires were received. The total return rate of the questionnaires of all addressed companies is $12.9 \%$.

Table 1

Structure of respondents by sectors

\begin{tabular}{|l|c|c|}
\hline \multicolumn{1}{|c|}{ Sector } & Frequency & Percentage \\
\hline Manufacturing & 78 & $44.1 \%$ \\
\hline Automotive & 12 & $6.8 \%$ \\
\hline Construction & 15 & $8.5 \%$ \\
\hline Engineering & 16 & $9 \%$ \\
\hline Agriculture & 15 & $8.5 \%$ \\
\hline Other & 41 & $23.2 \%$ \\
\hline Number of respondents & 177 & $100 \%$ \\
\hline
\end{tabular}

Source: own.

Table 1 illustrates that the largest sample of the firms is from sectors Manufacturing (44.1\%), Engineering (9\%), Construction (8.5\%) and Agricultural (8.5\%). 
The survey was divided into several parts - functions of budgets, effectiveness of budgets and updating of operational budgets. The main findings are presented in this article.

In the upcoming section, we provide some important descriptive statistics that can be compared with some similar research work, e.g. Libby and Lindsey (2010): for some selected attributes, we further compare mean, standard deviation or especially median as a value that is not skewed so much by extremely large or small values; thus it may give a better intuitive idea of the survey. At the end of the section, we investigate some potential interesting dependencies using the chi-square test.

\section{RESULTS}

At first, the research was focused on the general approach by the firms to budgeting system. Table 2 shows whether the budget is used for control. Based on the literature review, the results were compared with findings from the similar research by Libby and Lindsay (2010).

Table 2

The usage of budgets for control (Part 1)

\begin{tabular}{|l|c|c|}
\hline Are the budgets used for control? & Frequency & Percentage \\
\hline Yes & 157 & $88.70 \%$ \\
\hline No & 20 & $11.30 \%$ \\
\hline
\end{tabular}

Source: own.

As can be seen, Czech firms are mostly satisfied with their budgeting system. In comparison, results from the Canada and USA show that $78.9 \%$ of interviewed companies use the budgets for controlling aims. In the Czech Republic, the usage of budgets for control is standard for more than $88 \%$ companies from the sample. The negative answer was chosen mostly by firms from Agriculture (26.67\% of them), Construction (13.33\% of them) and Engineering (12.50\% of them).

The second question examined whether organizations planned to abandon using budgets for control.

Table 3

The usage of budgets for control (Part 2)

\begin{tabular}{|l|c|c|}
\hline $\begin{array}{l}\text { Do you plan to abandon the usage of budgets } \\
\text { for control? }\end{array}$ & Frequency & Percentage \\
\hline Yes & 4 & $2.55 \%$ \\
\hline No & 149 & $94.90 \%$ \\
\hline Possibly & 4 & $2.55 \%$ \\
\hline
\end{tabular}

Source: own. 
Actually a very small sample of interviewed companies planned to cease using budgets for control. This is a further confirmation about a minimal dissatisfaction with current budgeting system. Among the four companies who answered negatively for this question, there are enterprises represented from the manufacturing and construction sectors.

The second part of the survey deals with budgeting as a tool to adapt to changes in the business environment. The third question examined whether companies rely on budgeting as a tool to adapt to changes.

Table 4

Budgeting as an auxiliary tool in adaptation to changes (Part 1)

\begin{tabular}{|l|c|c|}
\hline $\begin{array}{l}\text { I. Evaluate how your company relies on budgeting } \\
\text { as a tool when adapting to changes on market. }\end{array}$ & Frequency & Percentage \\
\hline 1 - does not rely & 26 & $14.69 \%$ \\
\hline 2 - slightly relies & 31 & $17.51 \%$ \\
\hline 3 - medium relies & 90 & $50.85 \%$ \\
\hline $4-$ considerably relies & 30 & $16.95 \%$ \\
\hline
\end{tabular}

Source: own.

The majority of addressed companies responded that their reliance on budgeting is medium. This answer is a median and it was set mostly by the manufacturing (46.15\% of them), engineering (43.75\% of them) and automotive companies (33.33\% of them). The mean of the answers is 2.70 .

Table 5

Budgeting as an auxiliary tool in adaptation to changes (Part 2)

\begin{tabular}{|l|c|c|}
\hline $\begin{array}{l}\text { II. Evaluate the effectiveness of budgeting process } \\
\text { when adapting to changes on market. }\end{array}$ & Frequency & Percentage \\
\hline$-3=$ strictly ineffective & 4 & $0.56 \%$ \\
\hline$-2=$ ineffective & 25 & $6.78 \%$ \\
\hline$-1=$ rather ineffective & 37 & $15.25 \%$ \\
\hline $0=$ neutral & 71 & $20.11 \%$ \\
\hline$+1=$ rather effective & 27 & $14.12 \%$ \\
\hline$+2=$ effective & 12 & $2.26 \%$ \\
\hline$+3=$ highly effective & 1 & 20.90 \\
\hline
\end{tabular}

Source: own. 
From the opposite side, almost $15 \%$ of companies indicated that they do not rely on budgeting. The biggest scepticism regarding budgeting was considered by enterprises from the construction $(40 \%)$, manufacturing $(12.82 \%)$ and engineering sectors $(6.25 \%)$.

The next question researched the effectiveness of budgeting in adaptability to changes. The results are submitted below.

As can be seen, the budgeting is a neutral managerial tool for almost half of the respondents and, moreover, the answer is a median on our scale while it was observed to be "rather effective" by Libby and Lindsay (2010) in Canada. The mean is -0.25 . Viewed by sectors, only in the automotive industry do more than $50 \%$ of respondents evaluate the effectiveness of budgeting on the scale between +1 and +3 (totally $58.33 \%)$. Negative answers on the scale between -3 and -1 were chosen mostly by firms from the engineering (31.25\%), manufacturing (21.80\%) and construction sectors $(20 \%)$.

The third part of the research refers about the updating procedures of the operational budgets.

Updating of the operational budget (Part 1)

\begin{tabular}{|l|c|c|}
\hline $\begin{array}{l}\text { III. Choose the answer describing how the } \\
\text { operational budget is updated in your company. }\end{array}$ & Frequency & Percentage \\
\hline The authorized budget is fixed and cannot be edited. & 43 & $24.29 \%$ \\
\hline The budget is edited as needed. & 50 & $28.25 \%$ \\
\hline $\begin{array}{l}\text { The budget is edited during planned formalized review. } \\
\text { The budget is edited when preparing the next rolling } \\
\text { budget is approved. }\end{array}$ & 67 & $37.85 \%$ \\
\hline
\end{tabular}

Source: own.

Table 6 shows the results of how the operational budget is updated in the companies. As can be seen, no general trends can be observed in this field. The budget is fixed in almost quarter of interviewed firms mostly in the construction (40\%), engineering (31.25\%) and manufacturing firms $(23.08 \%)$. On the other hand, less than $10 \%$ of interviewed firms work with rolling budget which is defined as one of the modern progressive method (Crosson \& Needles, 2014). According to the survey, rolling budgeting is used in the automotive $(16.67 \%)$, construction $(13.33 \%)$ and engineering $(12.50 \%)$.

The following set of questions is based on various types of situations which occur in budgeting process. 
Table 7

Updating of the operational budget (Part 2)

\begin{tabular}{|c|c|c|c|c|c|c|}
\hline & $\begin{array}{l}1 \text { - never } \\
\text { happened }\end{array}$ & $\begin{array}{l}2 \text { - occasionally } \\
\text { happened }\end{array}$ & $\begin{array}{l}3 \text { - regularly } \\
\text { happened }\end{array}$ & mean & st. dev. & median \\
\hline & \multicolumn{6}{|c|}{ How often in the last two years did this situation happen in your company: } \\
\hline A. & \multicolumn{6}{|c|}{$\begin{array}{l}\text { Unspent funds were spent at the end of the budget period as a procuration against budget } \\
\text { increase in next year. }\end{array}$} \\
\hline \multirow{2}{*}{$\begin{array}{l}\text { Freq. } \\
\%\end{array}$} & 112 & 49 & 16 & 1.46 & 0.43 & 1 \\
\hline & 63.28 & 27.68 & 9.04 & & & \\
\hline B. & \multicolumn{6}{|c|}{$\begin{array}{l}\text { Necessary costs were postponed to achieve budgetary targets (maintenance costs, advertisement, } \\
\text { staff training). }\end{array}$} \\
\hline \multirow{2}{*}{$\begin{array}{l}\text { Freq. } \\
\%\end{array}$} & 55 & 103 & 19 & 1.80 & 0.38 & 2 \\
\hline & 31.07 & 58.19 & 10.73 & & & \\
\hline C. & \multicolumn{6}{|c|}{$\begin{array}{l}\text { At the end of the reporting period, sales were accelerated to achieve the budgetary targets. These } \\
\text { sales would be normally realized during the next budget period. }\end{array}$} \\
\hline \multirow{2}{*}{$\begin{array}{l}\text { Freq. } \\
\%\end{array}$} & 99 & 68 & 10 & 1.50 & 0.36 & 1 \\
\hline & 55.93 & 38.42 & 5.65 & & & \\
\hline D. & \multicolumn{6}{|c|}{$\begin{array}{l}\text { If the budgetary target was not reached, the budget is increased by costs that would be normally } \\
\text { incurred in the next budgetary period. }\end{array}$} \\
\hline \multirow{2}{*}{$\begin{array}{l}\text { Freq. } \\
\%\end{array}$} & 110 & 62 & 5 & 1.41 & 0.30 & 1 \\
\hline & 62.15 & 35.03 & 2.82 & & & \\
\hline E. & \multicolumn{6}{|c|}{$\begin{array}{l}\text { The manager set the budgetary targets under expected results for better evaluation from } \\
\text { supervisor or to get a bonus salary (this behaviour is known as game theory). }\end{array}$} \\
\hline \multirow{2}{*}{$\begin{array}{l}\text { Freq. } \\
\%\end{array}$} & 89 & 76 & 12 & 1.56 & 0.38 & 1 \\
\hline & 50.28 & 42.94 & 6.78 & & & \\
\hline
\end{tabular}

Source: own.

This part of the questionnaire was formed according to similar one by Libby and Lindsay (2010); the results analyse the so-called budget gaming. As we can see in practice of Czech firms, it is no exception to make budgetary adjustments according to manager's needs. This trend can be observed especially in later payment of necessary costs $(58.19 \%$ of companies occasionally do it, $10.73 \%$ of companies regularly do it); only for this question, the median is different from the answer " 1 - never happened" - in other words, the mean of the median is 1.2. Results of the survey also show that almost half of the interviewed companies $(42.94 \%)$ occasionally set the budgetary targets under expected results for better evaluation from supervisor or to get a bonus salary. For the first question (A), the standard deviation is the highest of all the questions A.-E. On other hand, question $\mathrm{D}$ has the lowest values of means and standard deviations. 
Generally, we could observe, that negative behavioural consequences, which had been verified by this part of the study and are based on the Libby and Linsay (2010) study are not very strong and in some cases only occasional.

Finally, we made several statistical tests. Specifically, we tested potential dependencies between questions I, II and III (that are presented in tables 4, 5 and 6) and company size as well as company "bistory."

In the questionnaire, 147 respondents claimed that their company has $100-500$ of employees while 30 companies claimed that the company has over 500 employees. On significance level of 5\% (i.e., $\alpha=0.05$ ), we do not reject all the three null hypotheses on independence of company size and questions I.-III. (see Table 8).

Furthermore, the respondents have chosen among the following options regarding the company history: the company was founded a) by Czech owner before 1990, b) by Czech owner after 1990, c) by Czech owner before 1990 but passed to foreign owner, d) by Czech owner after 1990 but passed to foreign owner and e) by foreign owner on a greenfield site. Similarly as for the company size, we tested the null hypotheses on independence between company history and questions I and III. Note that the test was not possible for question II since assumptions for chi-square tests were not fulfilled. On significance level of $5 \%$, we do not reject the null hypothesis on independence of company history and questions I but we reject the null hypothesis on independence of company history and question III, i.e. how the operational budget is updated in your company (see Table 8).

Table 8

P-values describing the tested dependencies of questions I-III on company size and company "history"

\begin{tabular}{|l|c|c|c|}
\hline & I. & II. & III. \\
\hline Company size & 0,060 & 0,108 & 0,146 \\
\hline Company history & 0,135 & - & 0,001 \\
\hline
\end{tabular}

\section{DISCUSSION AND CONCLUSION}

As presented in the literature review, traditional budgeting has been assiduously criticized over the last decades. The main reasons of criticism by experts and academics are based on lack of adaptability for unexpected changes of conditions and the annual period of reporting, both factors which do not reflect the current business environment of permanent changes.

With these statements, the results of submitted survey were confronted. The data for research was collected via a web-based questionnaire; 177 of them were completed by addressed companies. The sample was consisted by medium-size and large companies from manufacturing, automotive, construction, engineering and other sectors. Research questions were focused on functions of budgets, adaptation of budgeting to changes in business environment, updating procedure of operational budgets and reactions of companies to various types of situations during budgeting,

In summary, the results display some several trends. As in the USA and Canada (Libby \& Lindsay, 2010), a low number of Czech firms does not use the budgets for control or plan to abandon it. In our sample, we also observed the significantly higher number of the firms which use budgets for control in the Czech sample than in North American sample. It could be explained as the lower adoption rate of modern performance management methods in Czech environment. 
Reliance of companies on budgeting is considered as medium. The significant reliance was identified by manufacturing companies ( $46.15 \%$ ) while the biggest scepticism was shown by construction firms (40 $\%)$. Specifics of construction enterprises relate to the fact that the budget is usually included in the initial construction project. That is the reason why each change during the realization of a project is very limited.

From answers of respondents, we can observe that effectiveness of budgeting in adaptability to market changes is neutral. Only in the automotive industry do more than $50 \%$ of respondents evaluate the effectiveness of budgeting as rather effective or effective. Negative answers (budget is rather ineffective, ineffective or strictly ineffective) were chosen mostly by firms from engineering $(31.25 \%)$.

The last set of questions were the key part to assess the flexibility of budgeting in the Czech business environment. The authors defined five potential situations in the company during budgeting. The survey brought some significant results which refer about budgeting as a not-effective managerial tool. In every question, more than third of the total interviewed firms was admitted that the results of budgets are modified. The causes are different. For example, the managers do not allow an increase of the budget to next year due to excellent results in the current year. On the other hand, the individuals who cannot fulfil the planned results postponed the payments to achieve their plans.

Results of the survey also show that almost half of the interviewed companies (42.94\%) occasionally set the budgetary targets under expected results for better evaluation from a supervisor or to get a bonus salary. In addition, we must observe that this number may not be accurate because most of these managers would presumably be ashamed of this behaviour. Finally, we have identified a dependency between the socalled company history and the question on how is the operational budget updated in the company, which brings a potential motivation for a further research analysis.

\section{ACKNOWLEDGEMENT}

This paper is one of the research outputs of the project GA 17-13518S/P403 "Determinants of budgeting and performance measurement systems design and impact of these systems on organizational behaviour and organizational perform" registered at Czech Science Foundation and was supported by the Internal Grant Agency of Tomas Bata University in Zlin under the project number IGA/FaME/2016/005.

\section{REFERENCES}

Banovic, D., (2005). Evolution and critical evaluation of current budgeting practices. University of Ljubljana.

Blocher, E. J., Chen, K. H., \& Li, T. W. (2002). Cost Management: A Strategic Emphasis. McGraw-Hill International, New York, NY.

Cardos, I. R. (2014). New trends in budgeting - a literature review. SEA - Practical Application of Science, 2(2).

Crosson, S.V., Needles, B.E., (2013). Managerial Accounting. Cengage Learning, 10th Edition.

Drury, C. (2000). Management \& Cost Accounting. London: Thomson.

Garrison, R. H., Noreen, E. W., \& Brewer, P. C. (2014). Managerial Accounting for Managers. New York: McGraw-Hill Irwin.

Hansen, S. C., Otley, D. T., \& Van der Stede, W. A. (2003). Practice developments in budgeting: an overview and research perspective. Journal of Management Accounting Research, 15(1), 95-116.

Hänninen, V. (2013). Budgeting at a crossroads - the viability of traditional budgeting - a case study. Aalto University School of Business.

Henttu-Aho, T., \& Järvinen, J. (2013). A field study of the emerging practice of beyond budgeting in industrial companies: an institutional perspective. European Accounting Review, 22(4), 765-785.

Hilton, R. W. \& Platt, D. E. (2013). Managerial Accounting: Creating Value in a Dynamic Business Environment. McGraw Hill Higher Education. 
Hope, J., \& Fraser, R. (2003). Beyond budgeting: How managers can break free from the annual performance trap. Boston, Mass.: Harvard Business School Press.

Horngren, C. T. (2009). Cost accounting: a managerial emphasis. Upper Saddle River: Pearson Prentice Hall.

Král, B. (2010). Manažerské účetnictví. Praha: Management Press.

Libby, T., \& Lindsay, R. M. (2010). Beyond budgeting or budgeting reconsidered? A survey of North-American budgeting practice. Management Accounting Research, 21(1), 56-75. doi:10.1016/j.mar.2009.10.003.

Libby, T., \& Lindsay, R. M. (2007). Beyond budgeting or better budgeting?. Strategic Finance, 89(2), 46-51.

Nazli Nik Ahmad, N., Sulaiman, M., \& Alwi, N. M. (2003). Are budgets useful? A survey of Malaysian companies. Managerial Auditing Journal, 18(9), 717-724.

Neely, A., Bourne, M., \& Adams, C. (2003). Better budgeting or beyond budgeting?. Measuring Business Excellence, 7(3), 22-28.

Neely, A., Sutcliffe, M. R. \& Heyns, H. R. (2001). Driving Value through Strategic Planning and Budgeting. London: Accenture.

Østergren, K., \& Stensaker, I. (2011). Management control without budgets: a field study of 'beyond budgeting'in practice. European Accounting Review, 20(1), 149-181.

Pietrzak, Ż. (2013). Traditional versus activity-based budgeting in non-manufacturing companies. Social Sciences, 82(4), 26-37.

Popesko, B., Novák, P., Papadaki, S., \& Hrabec, D. (2015). Are the traditional budgets still prevalent: the survey of the czech firms budgeting practices. Transformation in Business \& Economics, 14, 42-57.

Šiška, L. (2016). The Contingency Factors Affecting Management Accounting in Czech Companies. Acta Universitatis Agriculturae et Silviculturae Mendelianae Brunensis, 64(4), 1383-1392.

Wagner, J. (2014). Performance Management and Measurement Research in the Czech Republic: 1993-2013, IDIMT2014: Networking Societies - Cooperation and Conflict, Book Series: Schriftenreihe Informatik, 43, Proceedings of 22nd Interdisciplinary Information Management Talks (IDIMT) Conference, Podebrady, Czech Republic. 